\title{
Facilitation of the Estuary/Ocean
} Subgroup

for Research, Monitoring, and Evaluation, FY06 Annual Report

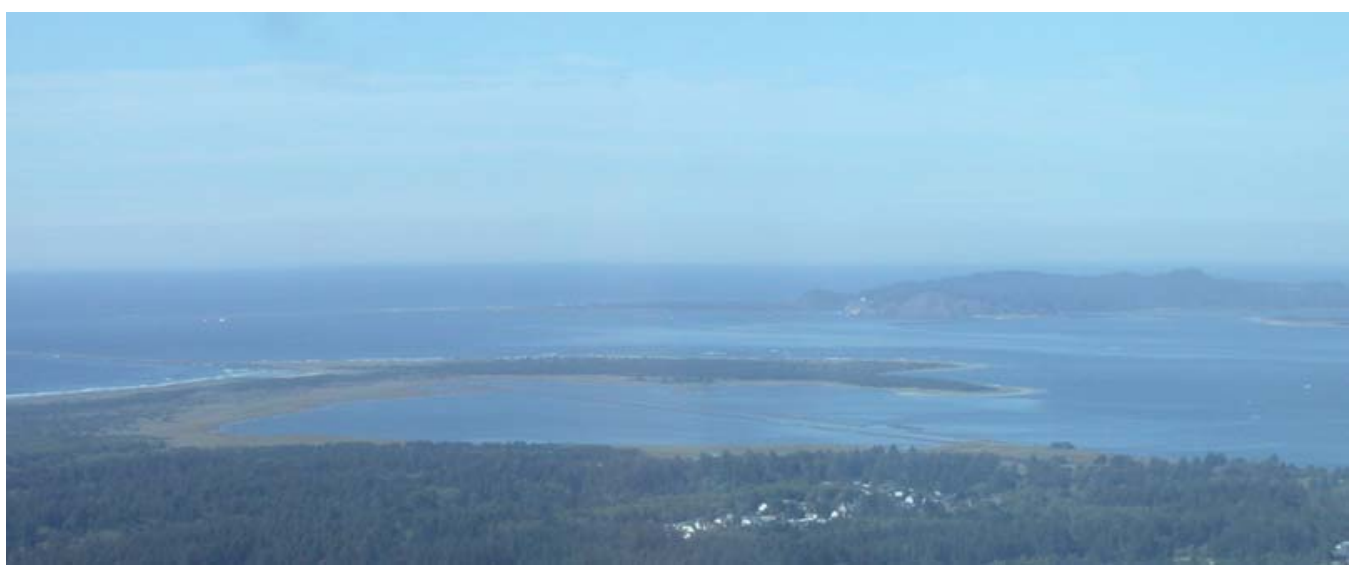

Final Report

September 30, 2006

Prepared for the Bonneville Power Administration Under a Related Services Agreement with the U.S. Department of Energy Contract DE-AC05-76RLO1830 


\section{DISCLAIMER}

This report was prepared as an account of work sponsored by an agency of the United States Government. Neither the United States Government nor any agency thereof, nor Battelle Memorial Institute, nor any of their employees, makes any warranty, express or implied, or assumes any legal liability or responsibility for the accuracy, completeness, or usefulness of any information, apparatus, product, or process disclosed, or represents that its use would not infringe privately owned rights. Reference herein to any specific commercial product, process, or service by trade name, trademark, manufacturer, or otherwise does not necessarily constitute or imply its endorsement, recommendation, or favoring by the United States Government or any agency thereof, or Battelle Memorial Institute. The views and opinions of authors expressed herein do not necessarily state or reflect those of the United States Government or any agency thereof.

PACIFIC NORTHWEST NATIONAL LABORATORY

operated by BATTELLE for the

UNITED STATES DEPARTMENT OF ENERGY

under Contract DE-AC05-76RL01830

Cover Photo (by G. Johnson): View of the Mouth of the Columbia River with Trestle Bay in the foreground and the Pacific Ocean in the background. 


\section{Facilitation of the Estuary/Ocean Subgroup \\ for Research, Monitoring, and Evaluation, FY06 Annual Report}

Gary E. Johnson

Final Report

September 30, 2006

Prepared for the Bonneville Power Administration Under a Related Services Agreement with the U.S. Department of Energy Contract DE-AC05-76RLO1830

Pacific Northwest National Laboratory

Marine Sciences Laboratory

Sequim, Washington 98382 



\begin{abstract}
This annual report is a deliverable for fiscal year 2006 (FY06) for Project 2002-077-00, Facilitation of the Estuary/Ocean Subgroup (EOS). The EOS is part of the research, monitoring, and evaluation (RME) effort the Action Agencies (Bonneville Power Administration, U.S. Army Corps of Engineers, U.S. Bureau of Reclamation) developed in response to the 2000 and 2004 Biological Opinions on operation of the Federal Columbia River Power System (FCRPS). The goal of the EOS project is to facilitate activities of the estuary/ocean RME subgroup as it coordinates implementation of the Estuary RME Plan. In FY06, EOS project accomplishments included 1) subgroup meetings; 2) participation in the estuary work group of the Pacific Northwest Aquatic Monitoring Partnership; 3) project management via the project tracking system, PISCES; 4) quarterly project status reports; and 5) a major revision to the Estuary RME Plan (new version May 2006) based on comments by EOS members, the Independent Scientific Review Panel, and other reviewers. In the context of uncertainty about the direction of the federal RME due to litigation on the FCRPS Biological Opinion, FY06 activities for the EOS project resulted in expanded substantive coordination with other regional RME forums, project tracking infrastructure, and a new version of the Estuary RME Plan.
\end{abstract}




\section{Preface}

The Bonneville Power Administration (BPA) contracted with the Pacific Northwest National Laboratory (PNNL) to coordinate and facilitate workings of the Estuary/Ocean Subgroup (BPA Project No. 2002-077-00; Contract No. 652-00022, Amendment 3). Initiated in 2002, the EOS is composed of members from BPA, the U.S. Army Corps of Engineers (USACOE), the Lower Columbia River Estuary Partnership (LCREP), the National Oceanic and Atmospheric Administration National Marine Fisheries Service (NOAA Fisheries), and PNNL's Marine Sciences Laboratory. It is one of multiple work groups in the federal RME effort designed to implement provisions in the 2000 and 2004 Biological Opinions on Operation of the Federal Columbia River Power System (NOAA Fisheries 2000; 2004). The purpose of project 2002-077-00 is to coordinate and facilitate activities of the EOS. For more information about the EOS, please contact Gary Johnson (503-417-7567).

The estuary/ocean subgroup is tasked by NOAA Fisheries and the Action Agencies with developing a RME plan for the Columbia River estuary, including the plume. After review by the Action Agencies, which are currently ongoing, the Estuary RME Plan ${ }^{1}$ is intended to be available from BPA as a stand-alone document.

\section{Acknowledgments}

Important contributions to this project were made by Blaine Ebberts (Portland District, Corps of Engineers), Cathy Tortorici (NOAA Fisheries), Jim Geiselman and Tracey Yerxa (BPA), Scott McEwen and Jill Leary (Estuary Partnership), Charlie Paulsen (Paulsen Environmental Research, Inc.), Al Giorgi and Tracey Hillman (BioAnalysts, Inc.), John Skalski (University of Washington), and Heida Diefenderfer, Terri Gilbride, Jan Slater, and Ron Thom (PNNL).

${ }^{1}$ Johnson, G.E., H. Diefenderfer, B. Ebberts, C. Tortorici, S. McEwen, J. Leary, T. Yerxa, and J. Skalski. 2006. Federal Columbia River Estuary Research, Monitoring, and Evaluation Program. PNNL-14632, Richland, WA. Draft, May 2006. 


\section{Acronyms}

AFEP - Anadromous Fish Evaluation Program

BiOp - biological opinion

BPA - Bonneville Power Administration

CREDDP - Columbia River Estuary Data Development Program

CREST - Columbia River Estuary Study Taskforce

CSMEP - Collaborative Systemwide Monitoring and Evaluation Project

EOS - Estuary/Ocean Subgroup

ERME - Estuary research, monitoring, and evaluation

ERMECC - Estuary RME Coordination Committee

ESA - Endangered Species Act

ESU -- evolutionarily significant unit

FCRPS - Federal Columbia River Power System

FY06 - Fiscal Year 2006

ISRP - Independent Scientific Review Panel

LCFRB - Lower Columbia Fish Recovery Board

LCREP - Lower Columbia River Estuary Partnership

MRE - Monitoring, Research, and Evaluation effort led by the Lower Columbia Fish Recovery Board

NED - Northwest Environmental Data network

NOAA - National Oceanic and Atmospheric Administration

NOAA Fisheries - NOAA National Marine Fisheries Service

NPCC - Northwest Power and Conservation Council

ODEQ - Oregon Department of Environmental Quality

PER - Paulsen Environmental Research

PISCES - the name for the BPA project tracking system

PNAMP - Pacific Northwest Aquatic Monitoring Partnership

PNNL - Pacific Northwest National Laboratory

PSMFC - Pacific States Marine Fisheries Commission 
RME - research, monitoring, and evaluation

UPA - Updated Proposed Action

USACOE - US Army Corps of Engineers

UW - University of Washington 


\section{Table of Contents}

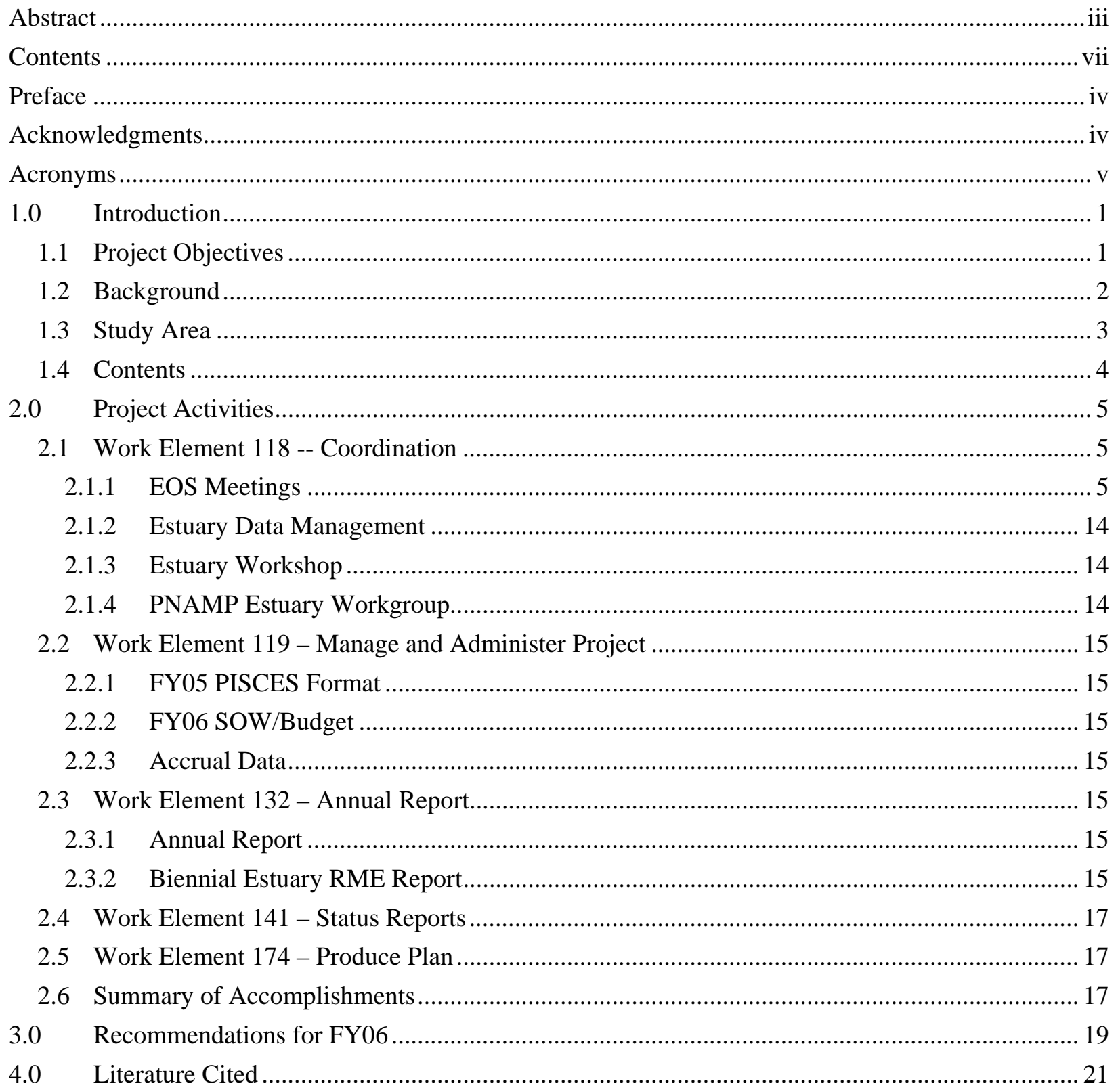




\subsection{Introduction}

This document is the annual report for fiscal year 2006 (FY06) for Project 2002-077-00, Facilitation of the Estuary/Ocean Subgroup (EOS). The EOS is part of the research, monitoring, and evaluation (RME) effort the Action Agencies (Bonneville Power Administration, U.S. Army Corps of Engineers, U.S. Bureau of Reclamation) developed in response to the 2000 and 2004 Biological Opinions on operation of the Federal Columbia River Power System (NOAA Fisheries 2000; 2004). For the purposes of this report, the Columbia River estuary includes mainstem waters from Bonneville Dam down through the lower river and estuary into the ocean plume.

The goal of this project was to facilitate activities of the estuary/ocean RME subgroup (EOS) as it coordinated implementation of the estuary RME plan in FY06 with the PNAMP estuary workgroup, the Columbia Basin Fish and Wildlife Authority's Collaborative Systemwide Monitoring and Evaluation Program (CSMEP), the Northwest Power and Conservation Council's (NPCC) Fish and Wildlife Program, and the federal Updated Proposed Action (UPA) team.

\subsection{Project Objectives}

The EOS project had the following objectives for FY06, designated by numbered categories in the PISCES project tracking system:

118 Coordination -- Continue facilitation of the estuary/ocean RME subgroup, including coordination with

a) RME Technical/Policy Oversight Group and Federal Caucus - attend meetings and provide status reports as required;

b) PNAMP estuary workgroup - attend and participate in workgroup meetings and assist in the development of coordinated estuary planning and monitoring approaches within PNAMP;

c) CSMEP - inform CSMEP about estuary RME activities and coordinate as necessary;

d) RME Data Management Subgroup -- coordinate the estuary RME work with the developing data management effort for the basin-wide RME;

e) NPCC and UPA -- Convene annual estuary RME workshops to present new data, evaluate the conduct of the estuary RME program, exchange information, and provide input to the estuary/ocean RME subgroup.

119 Project Management -- Manage and administer the project according to BPA's "Work Element/Milestone” based project management and reporting system (PISCES).

132 Annual Report -- Produce an annual report of project activities, including a detailed outline for a biennial estuary RME summary report incorporating adaptive management recommendations at the 
program level for submittal to the Action Agencies, estuary restoration project leaders, and other related entities (e.g., subbasin planners, PNAMP).

141 Status Reports -- Produce quarterly status reports.

174 Plan -- Revise the estuary-RME plan (dated September 2005) as necessary as new information becomes available concerning RME in the Columbia River estuary.

\subsection{Background}

The function of the Columbia River estuary ${ }^{1}$ in the life history of threatened and endangered salmonids is more than simply serving as a corridor for passage between the tributaries and the Pacific Ocean. The estuary provides habitat for various life history stages of salmon and steelhead, ranging from the rearing and feeding of fry, fingerlings, and smolts to the passage upstream of adults (Bottom et al. 2001). Usage of estuary habitat by juvenile salmonids varies by species and life history stage (Rich 1920).

Generally, the closer the natal

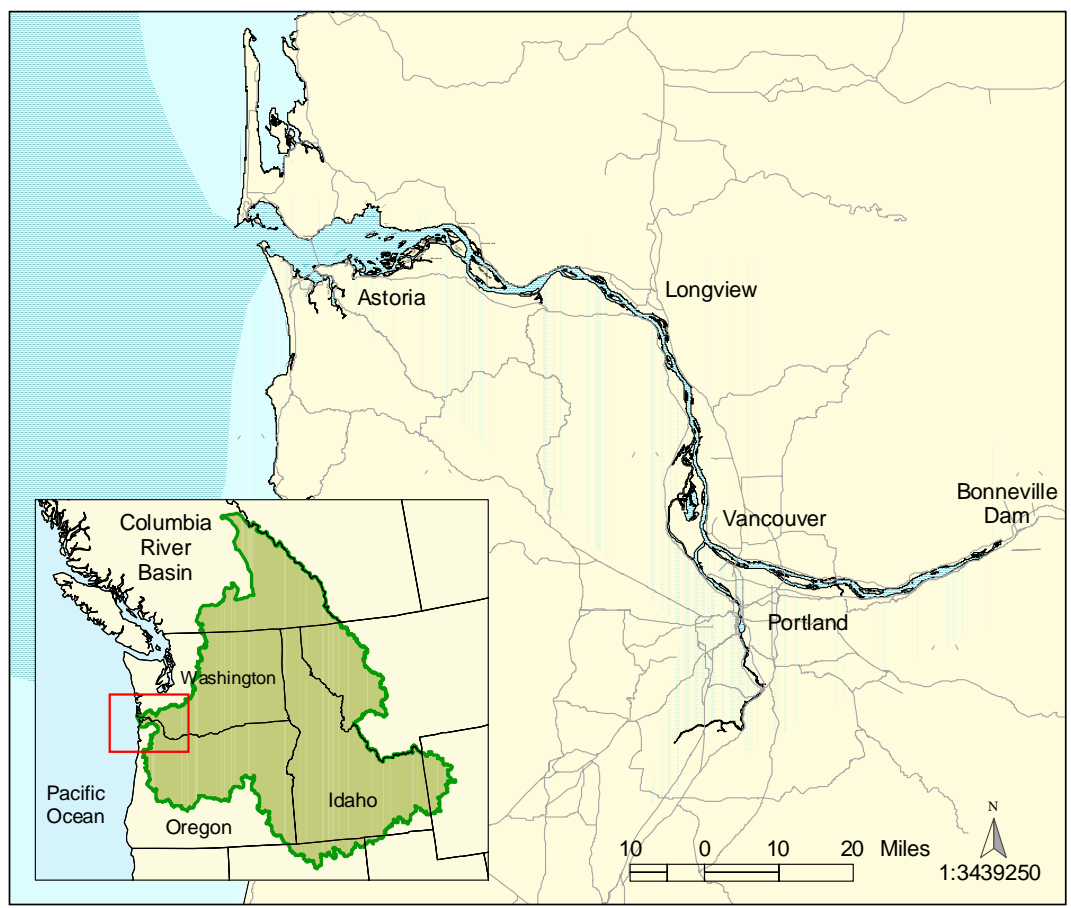
stream is to the estuary and the smaller the juvenile migrant, the more likely it is that juveniles will use estuary habitats as more than just a migration corridor. Information on salmon biology and ecology in the Columbia River estuary can be found in Bottom et al. 1984, 2001; Dawley et al. 1985a,b, 1986; Durkin et al. 1981; Kirn et al. 1986; Ledgerwood et al. 1991; McCabe et al. 1983, 1986; McConnell et al. 1983; and Reimers and Loeffel 1967. In recognition of the estuary's importance to salmon population viability, the 2000 and 2004 Biological Opinions (BiOp) on operation of the Federal Columbia River Power System called for the restoration of estuarine habitat as a pivotal action to avoid jeopardizing the continued existence of listed salmonid populations (NOAA Fisheries 2000; 2004), as well as comprehensive research, monitoring, and evaluation for listed salmon.

${ }^{1}$ The Columbia River estuary is defined as the tidally influenced portion of the river from Bonneville Dam to the plume. This is consistent with Bottom et al. (2001) and the Lower Columbia River Estuary Program (1999). Lower Columbia River tributaries are not part of the estuary RME study area. 
NOAA Fisheries and the Action Agencies established a process to develop a basin-wide RME plan that fulfills Action Items in the 2000 BiOp’s Reasonable and Prudent Alternatives and satisfies the Federal Columbia River Salmon Recovery Strategy (www.salmonrecovery.gov). The federal RME process involves a Policy Oversight Group and six technical subgroups: Status Monitoring, Effectiveness Research, Hydrosystem, Hatchery/Harvest, Data Management, and Estuary/Ocean (EOS). One outcome of the federal RME process was a draft Basin-wide RME Plan (Jordan et al. 2003). In FY06, however, federal RME occurred in the context of ongoing litigation on the legal standing of the Biological Opinions that created the RME process in the first place. Because of uncertainty in the outcome of the litigation, federal RME was instituted carefully with emphasis on expanded coordination with the states and tribes and other regional monitoring efforts.

For example, FY06 saw integration of federal FCRPS BiOp RME efforts with the Pacific Northwest Aquatic Monitoring Partnership (PNAMP). PNAMP is an assemblage of federal, state, and tribal agencies whose goal is “...to coordinate important scientific information at the appropriate scales needed to inform public policy and resource management decisions” (PNAMP 2004). PNAMP’s geographic scope includes the Pacific Northwest and northern California. Most of their efforts to date have involved tributary habitats, although in FY05 PNAMP coordination work extended into estuarine habitats, including the Columbia River estuary; this coordination continued in FY06.

Overall in FY06, estuary/ocean subgroup RME activities progressed as the Estuary RME Plan was coordinated and revised (Johnson et al. 2006). The document herein is the annual report of activities and accomplishments for the EOS project 2002-077-00 in FY06.

\subsection{Study Area}

A number of publications provide descriptive information about the Columbia River estuary: the Salmon at River's End report by Bottom et al. (2001); Fresh et al.'s (2004) Role of the Estuary in the Recovery of Columbia River Basin Salmon and Steelhead; the Biological Assessment for the Columbia River Channel Improvements Project by the U.S. Army Corps of Engineers (2001); the RPA Action 158 action plan by Berquam et al. (2003); the RPA Action 159 habitat restoration report by Johnson et al. (2003); and the Northwest Power and Conservation Council (NPCC) subbasin plan for the estuary (Lower Columbia River Estuary Partnership and Lower Columbia Fish Recovery Board 2004). Important earlier compendiums include The Columbia River Estuary and Adjacent Ocean Waters by Pruter and Alverson (1972); "Columbia River Estuary" in Changes in Fluxes in Estuaries: Implications from Science to Management by Dyer and Orth (1994); and Columbia River: Estuarine System by Small (1990), which contains reviews of earlier work supported by the Columbia River Estuary Data Development Program (CREDDP) on physical and biological processes (CREDDP 1984a, 1984b). Another comprehensive environmental study of the lower Columbia River was the Bi-State Water Quality Study (TetraTech 1996; Fuhrer et al. 1996), completed as part of the process to include the Columbia River estuary in the U.S. Environmental Protection Agency’s National Estuary Program. 


\subsection{Contents}

This FY06 annual report for the EOS project has five sections: Introduction, Project Activities, Summary of Accomplishments, Recommendations for FY07, and Literature Cited. The Activities and Accomplishments sections are organized by the work elements listed in the objectives (Section 1.1). In sum, the FY06 EOS project resulted in expanded, substantive coordination with other regional RME forums, project tracking infrastructure, and a new version of the Estuary RME Plan. 


\subsection{Project Activities}

\subsection{Work Element 118 -- Coordination}

\subsubsection{EOS Meetings}

The EOS met four times in FY06: February 7, March 14, April 13, and June 21, 2006.

Highlights of the meeting February 7, 2006 are as follows:

Participants: Gary Johnson and Heida Diefenderfer (PNNL), Jill Leary and Scott McEwen (Estuary Partnership), and Cathy Tortorici (NOAA Fisheries). Yerxa (BPA) could only participate briefly at the beginning of the meeting.

Meeting Objectives: 1) Discuss updates on RME-related activities, and 2) discuss revisions to the EPRME Plan.

\section{$\underline{\text { Updates }}$}

Federal RME - Update not available.

MRE - A Monitoring, Research, and Evaluation effort led by the Lower Columbia Fish Recovery Board (LCFRB) is underway. The Corps (Ebberts), the Estuary Partnership (McEwen), and NOAA (Scranton) have been participating. There's an MRE meeting scheduled for 2/21/06; McEwen to attend. At a previous MRE meeting, Ebberts provided existing pertinent materials, including the 159 Plan, EPRME Plan, and Cumulative Effects FY04 report. Tortorici pressed Scranton to point out to LCFRB that, between the Estuary Partnership’s Monitoring Strategy and the EOS’s EP-RME Plan, monitoring plans for the mainstem lower river and estuary exist, and MRE work there would be duplicative. She said, and the EOS agrees, LCFRB's MRE effort should focus on the lower river tributary watersheds in Washington State. Diefenderfer has attempted to contact LCFRB to make sure revisions to the EP-RME Plan include any appropriate new information from LCFRB. Ebberts offered to contact Breckle at LCFRB to coordinate EOS's EP-RME and LCFRB's MRE.

NOAA Recovery Plan RME - The Recovery Plan for listed salmonids in the Willamette and Lower Columbia Rivers will include an RME section. Tortorici will obtain this and send it to Johnson to distribute to the EOS.

PNAMP Estuary Workgroup - Tortorici reported workgroup activities are on hold. Leary said the effort to inventory all regional monitoring programs and projects was contracted to PSMFC's StreamNet group. They do not want the PNAMP Estuary Workgroup to do anything until StreamNet is ready with an "inventory template" and questionnaire. 
CSMEP - The Collaborative Systemwide Monitoring and Evaluation Program will be convening a joint workshop with PNAMP on March 16 and 17, 2006. Yerxa, Diefenderfer, McEwen, and Learn plan to attend. Currently, CSMEP efforts do not include the lower river and estuary. At the EOS meeting 9/30/05, Tortorici noted the estuary needs to be "tagged" as much as possible to stay on everyone's radar. The EOS agreed this was an appropriate general strategy. Here's an announcement for the 3/16 workshop:

The Collaborative Systemwide Monitoring and Evaluation Project (CSMEP) and the Pacific Northwest Aquatic Monitoring Partnership (PNAMP) are pleased to announce the Annual Pacific Northwest Monitoring Practitioner's Workshop on March 16-17, 2006, at the Ambridge Event Center, Portland, Oregon. The purpose of the workshop is to review a succession of RM\&E work products designed to achieve standardization and to coordinate and exchange information on aquatic resource monitoring and evaluation efforts in the Pacific Northwest.

NED - Leary attended a meeting of the Northwest Environmental Data-network. This is where she learned about StreamNet's role in PNAMP. NED's status is not clear. It is an effort by NOAA Fisheries with funding from BPA to provide an "umbrella" structure to existing regional databases. Umbrella means standard terminology, accessibility, dissemination, etc. At their 9/30/05 meeting, the EOS noted that data management remains an issue for the estuary.

Tidal Freshwater Pilot Monitoring Study - Yerxa reported that the ISRP ruled "Do Not Fund" on the research proposed for FY06. She said BPA would be meeting the week of February 13-17 to discuss next steps.

Washington State Governor's Forum on Monitoring - Leary has been participating. There is going to be an "Indicator Summit" that she'll attend. Leary will obtain information on the Forum and send it to Johnson who will distribute it to the EOS. Ebberts will contact Brace to inform her about the Monitoring Protocols for Estuary Action Effectiveness Research that is being developed in the Corp's Cumulative Effects project. Diefenderfer will talk with Thom about the Forum on Monitoring.

BiOp Remand - To be completed by the end of September 2006, according to the schedule today. The following material was copied from the Federal Caucus website (www.almonrecovery.gov).

January 3, 2006: Today the Department of J ustice filed its first quarterly status report on behalf of NOAA Fisheries in the remand of the 2004 FCRPS Biological Opinion. Federal agencies have been meeting with regional states and tribes to develop a collaboration plan for the remand process. The current status of these discussions is memorialized in three documents which are the collective product of the participants in the collaborative process. Materials include: the 2004 FCRPS BiOp Remand Collaboration Process; Update on the Nature and Scope of the FCRPS Proposed Action; and Conceptual Framework for the Remand Process including the Jeopardy Analysis. Any Party or amici have five days to file comments on the status report to be followed by a status hearing before the Court. 


\section{Estuary RME Plan}

At the direction of the EOS, and based on comments by ISRP and others on the 8/10/04 version of the EP-RME Plan (ISRP 2004), Johnson and Diefenderfer developed a working draft of new material for relationships; approach; goals; objectives; conceptual model; and monitored indicators. This document, which was emailed to the EOS for review prior to the meeting, served as the basis for a lively and productive discussion.

Relationships - The new figure depicting relationships among RME drivers and entities affecting and affected by the EP-RME Plan is an improvement, but it still needs work. The EOS offered constructive suggestions.

Approach - The Conceptual Model is the troublesome link because it is not detailed enough for specific RME planning for the estuary. We decided to move it out of the main chain between objectives and monitored indicators, but keep it in the plan. The approach also needs to have feedback loops, i.e., adaptive learning.

Goals - The multiple sources for goals are confusing. It's also confusing to have program-type goals mixed with RME-type goals. We will reorganize, take some literary license, and distill the goals with separate categories for program-type and RME-type.

Objectives - The EOS's discussion focused on the Status and Trend Monitoring objectives, although Diefenderfer explained the revised objectives for Action Effectiveness Research (transferred implementation monitoring to new category), Uncertainties Research (no changes at this time), and Implementation and Compliance Monitoring (new category based on input from ISRP and BPA). For the Status and Trend Monitoring objectives, we decided to consider removing the details on what to measure and collapse then down to one super objective. All objectives will be linked back to the goals in the objective table.

Conceptual Model - See notes above under approach. The EOS agreed that the model would likely be useful but that work remained to establish its place in the EP-RME Plan.

Monitored Indicators - Johnson explained that the old performance indicators and monitored attributes were not particularly useful because the performance indicators were merely names for objectives and we weren't really looking at performance relative to any performance standards. Therefore, it seems appropriate to let the objectives drive "monitored indicators." The EOS will consider this in the next version of the working draft.

$\underline{\text { Schedule (as of February 7, 2006) }}$

- February 9 to March 6 - Johnson and Diefenderfer revise working draft materials.

- March 7 - New version of working draft materials is due to the EOS.

- $\quad$ March 7-13 - EOS review period. 
- March 14 -- EOS meeting, 0900-1500 h at BPO. Is this okay? Please advise.

- $\quad$ April 3 - Review draft of complete new version of EP-RME Plan due to the EOS.

- April 3-12 - EOS review period.

- April 13 -- EOS meeting, 0900-1600 h at BPO.

- April 28- New version of EP-RME Plan is due, ready for release for review by interested parties.

- $\quad$ May 1 to June 30 - Regional review period.

- June 30 - Review comments are due.

- July 6 - EOS meeting, 0900-1500 h at BPO. Is this okay? Please advise.

- July 1 to July 28 - Revise based on comments.

- July 28 - Final 2006 version of the EP-RME Plan is due.

Highlights of the meeting March 14, 2006 are as follows:

Participants: Gary Johnson and Heida Diefenderfer (PNNL), Jill Leary and Scott McEwen (Estuary Partnership), Blaine Ebberts (Corps of Engineers, Portland District), and Cathy Tortorici (NOAA Fisheries).

Meeting Objectives: 1) Discuss updates on estuary RME-related activities, and 2) discuss revisions to the Estuary RME Plan.

\section{$\underline{\text { Updates }}$}

Federal RME - Update not available.

BiOp Remand - The collaboration process includes an RME group. Tortorici suggested, and the EOS agreed, we provide them our ERME Program document when it's ready. The new BiOp is due 9/30/06, although a motion has been filed by the plaintiffs to extend the due date.

PNAMP/CSMEP Workshop (March 16-17) - Many EOS members will be attending. We discussed the draft management questions for the estuary in the PNAMP/CSMEP workshop materials. (Johnson and Leary provided them to the estuary PNAMP group in fall 2005.) Leary explained that the purpose of the management questions is to provide guidance to BPA and NOAA for the BiOp Remand, the F\&W Program, and Recovery Planning.

NOAA Recovery Plan RME - Tortorici said the big push is on as the draft products for the Lower Columbia/Willamette Plan are due in June 2006. There is an estuary module where existing work is 
synthesized. The Estuary Partnership is working with Trask on this. It will be plugged into the Recovery Plan. ERME will be applicable to this effort.

MRE by LCFRB - The group will be meeting the week of March 20. Ebberts and Leary plan to attend. They will report back to the EOS.

Columbia River Management Scenarios Modeling Workshop - This is about Baptista's hydrodynamic model of the Columbia River estuary and plume. Tortorici suggested the EOS consider feeding this model into the ERME Program. It applies to Uncertainties Research objective no. 2. Part of the purpose of the model is to provide a tool to users in the lower river and estuary. The workshop resulted in three management scenarios: channel deepening, dike removal, and flow regulation.

NED - Leary reported that NED (Northwest Environmental Data network) is the real deal. BPA is looking to NED as a key piece in the adaptive management process.

EOS's Program/Project Inventory - The EOS went over the program and project inventory Leary and Johnson compiled. We will provide the inventory to the PNAMP inventory process when PNAMP is ready.

\section{EstuaryRME Plan}

Based on discussion at the previous EOS meeting (February 7, 2006), Johnson and Diefenderfer developed a working draft of new material for relationships; approach; goals; objectives; conceptual model; and monitored indicators. This document (Estuary RME Plan_Working document_030306_sent to EOS.DOC) was emailed to the EOS for review prior to the meeting. The document served as the basis for another lively and productive discussion.

Relationships - The figure depicting relationships among RME drivers and entities affecting and affected by estuary RME (ERME) is looking good; the EOS offered edits to improve the accuracy of the material.

Approach - The Conceptual Model is back in the main chain of events because we think it can provide the support we need for the ERME Program. We will need to explain how the conceptual model will be used. We'll also delineate the Adaptive Management portion of the Approach figure to provide more information for the reader.

New Materials - The EOS had numerous suggestions for additional materials. For example, we need to get reports from the BPA-funded plume and estuary ecology studies.

Goals and Objectives - The EOS spent a lot of time discussing the goals and objectives. We edited and formatted to make them clearer. The final outcome is attached at the end of these notes. We need to note that there are no Performance Standards. Ebberts noted that the Implementation and Compliance objectives should be part of Action Effectiveness Research; they are not because we used the RME structure from the federal RME effort. 
Conceptual Model -The EOS supported use of the model. We need to explain it in the context of ERME. It might be appropriate that the elements of Habitat Structure are derived from the UW's new estuary habitat classification; Leary to check with UW.

Monitored Indicators - The EOS wants the details about each indicator explained clearly in the plan. We need to do more work on the Monitored Indicators.

$\underline{\text { Schedule (as of March 14, 2006) }}$

- April 3 - Review draft of complete new version of ERME Program due to the EOS.

- April 3-12 - EOS review period.

- April 13 -- EOS meeting, 0900-1600 h at BPO. Comments due.

- April 28 - New version due, ready for release for review by interested parties, e.g., Bottom, Casillas, Geiselman, Hillman, Roegner, Sinks, Warren, Waste.

- $\quad$ May 1 to May 28 - Review period.

- May 28 - Review comments due to Johnson, who will distribute them to the EOS

- June 6 - EOS conference call to discuss the review comments.

- June 6-15 - Revise ERME Program document

- June 16 - Send out for wide-scale regional review, including the BiOp Remand RME group and NOAA Recovery planners

- July 14 - Comments due

- July 19 - EOS meeting, 0900-1500 h at BPO.

- July 19-28 - Revise based on comments.

- July 28 - Final 2006 version of the ERME Program due.

Highlights of the meeting April 13, 2006 are as follows:

Participants: Gary Johnson and Heida Diefenderfer (PNNL), Jill Leary and Scott McEwen (Estuary Partnership), Tracey Yerxa (BPA), and Cathy Tortorici (NOAA Fisheries; by phone).

Meeting Objectives: 1) Discuss updates on estuary RME-related activities, and 2) discuss revisions to the Estuary RME Plan. 


\section{$\underline{\text { Updates }}$}

BiOp Remand - The collaboration process includes an RME group. Tortorici has provide Kratz, Scranton, and Jordan (NOAA Fisheries) with the 4/3/06 draft of the ERME Program. They will consider it for estuary RME in the new BiOp due in September 2006.

PNAMP/CSMEP Workshop (March 16-17) - Diefenderfer, Ebberts, Leary, and Tortorici attended. Nothing substantial was new.

MRE by LCFRB - The group met during the week of March 20. Ebberts and Leary attended. Leary reported that they informed the MRE group of the EOS planning efforts for estuary RME. The MRE scope apparently will be in estuary tributary watersheds upstream of the confluence with the Columbia River.

NED - Leary reported on another NED (Northwest Environmental Data network) meeting. She said they are moving forward and that ERME needs to be linked to their effort. The EOS agreed.

BPA FY07-09 Solicitation - McEwen noted that the subbasin plans did not include RME; therefore, the Estuary Partnership used available guidance documents, such as the August 2004 version of the Estuary RME Plan. Tortorici said she is pushing to have NOAA weigh in on the projects during the review process. She will be involved with the review of the estuary province. Echoing McEwen, she said that they would use available RME guidance documents, like the current version of ERME.

\section{EstuaryRME Plan}

Based on discussion at the previous EOS meeting (March 14, 2006), Johnson and Diefenderfer developed a new working draft. This document (ERME Program_040306_sent to EOS.doc) was emailed to the EOS for review prior to the meeting. The document served as the basis for yet another lively and productive discussion.

Formalizing and Institutionalizing the ERME Program -- This topic concerns making the ERME Program a stable, sustainable reality. Tortorici pointed out that this would happen if the ERME Program were included in the new BiOp on FCRPS operations (see BiOp Remand update above). This also may be true, although to a lesser degree, in the BPA FY07-09 solicitation process. The EOS members will continue to work behind the scenes to give the ERME Program "legs."

Estimated Costs -- The issue of estimated costs for the ERME Program was raised by McEwen because this topic came up during work the Estuary Partnership is doing on the Estuary Module for the Recovery Plan for Lower Columbia River ESA-listed species. The EOS wondered if other aspects of federal RME were doing costing, so Tortorici volunteered to ask Kratz. Diefenderfer noted that costing comes to the heart of the scale and sampling intensity issues, i.e., costing would have to be organized by scale and/or sampling intensity. 
Review by the National Research Council -- Since we have reached the limit of two ISRP reviews on a given product, the EOS is interested in another formal, independent review body. Diefenderfer suggested the NRC has had initial conversations and will continue to pursue this avenue. Ebberts, Tortorici, and Yerxa will need to make sure such an NRC review is approved by their respective agencies.

Pilot Study -- The EOS discussed the Estuary Pilot Study and decided to hold off on it as part of the ERME program document pending the results of a meeting among BPA, the Corps, NOAA Fisheries, etc. that Yerxa will convene. The purpose of the meeting will be to discuss the ERME Program's Action Plan (the recommended activities), including the Estuary Pilot Study.

Map of Estuary RME Projects -- McEwen offered to develop a map of the estuary RME projects, coded by STM, AER, and UR. Johnson will visit the Estuary Partnership office to work on this with them.

EMAP -- EMAP continued to provide fuel for discussion at EOS meetings. Leary and Diefenderfer will contact the Oregon Department of Environmental Quality (ODEQ) and the Environmental Protection Agency (EPA), respectively, to gather more information about the experiences of others using EMAP in the Columbia River estuary.

Mainstem/Systemwide BPA FY07-09 Project Review Criteria -- This process includes the latest in uncertainties for the estuary and ocean. The EOS agreed to build this material into the UR section of the ERME Program.

$\underline{\text { Schedule (as of April 13, 2006) }}$

- April 28 - New version due, ready for release for review by select parties, e.g., Bottom, Casillas, Geiselman, Hillman, Waste.

- $\quad$ May 1 to May 28 - Review period.

- May 28 - Review comments due to Johnson, who will distribute them to the EOS

- June 6 - EOS conference call to discuss the review comments.

- June 6-15 - Revise ERME Program document

- June 16 - Send out for wide-scale regional review, including the BiOp Remand RME group and NOAA Recovery planners

- July 14 - Comments due

- July 19 - EOS meeting, 0900-1500 h at Battelle’s Portland Office (BPO).

- July 19-28 - Revise based on comments. 
- July 28 - Final 2006 version of the ERME Program due.

Highlights of the conference call June 21, 2006 are as follows:

Participants: Eric Braun and Blaine Ebberts (Corps of Engineers), Heida Diefenderfer and Gary Johnson (PNNL), Charlie Paulsen (PER), Cathy Tortorici (NOAA Fisheries), and Tracey Yerxa (BPA).

Objectives: 1) Discuss comments received on the May 2006 version of the Estuary RME Plan; and 2) decide next steps.

\section{Estuary RME Plan}

The May 2006 version of the Estuary RME Plan was sent to a select group of regional scientists for review. The EOS's intention was to develop a new version of the document based on these comments that would then be sent to a broad regional audience for comment and, ultimately, implementation. Comments were received from L. Caton (ODEQ), A. Giorgi and T. Hillman (BioAnalysts), R. Scranton (NOAA Fisheries), S. Simenstad (UW), and R. Thom (PNNL).

Johnson opened the discussion by asking the EOS if they had any comments or suggestions. Braun responded with several concerns of the Corps of Engineers, North Pacific Division. He cautioned that the Estuary Program goal statement is not official as it has not been "staffed" through the Corps' chain of command. Tortorici pointed out that this goal was based on work the Action Agencies and NMFS have been doing in the $\mathrm{BiOp}$ arena and it is implicit in BiOp negotiations. Braun said he would see if the goal statement is acceptable to his superiors in the Corps.

Braun made it clear that the Corps was not obligated to fund every action recommended in this plan. Johnson noted the existing caveat about this in the preface section of the document.

Another concern Braun raised dealt with the action plan and coordination sections of the Estuary RME Plan. He wondered who is going to implement the actions; who is going to be responsible to pay for them; who is going to follow-up to see the actions actually happened; what is the ERMECC's (Estuary RME Coordination Committee) role? The EOS recognized that these were policy issues the BPA and Corps, as Action Agencies, would need to negotiate with NMFS in the BiOp remand process. Yerxa and Braun said they would be meeting to discuss these matters. Tortorici added that the Federal RME Policy Group, also known as the "Gang of Four," should also weigh in on this topic.

Johnson solicited input on the myriad of monitoring indicators in the plan by asking the BPA, the Corps, and NMFS which indicators they thought were the most important, with the idea that these might be priority indicators. Tortorici thought this might be best done on a case-by-case basis. Yerxa noted the need to define which indicators BPA would fund and which they wouldn't.

Diefenderfer reminded the EOS that Simenstad commented about the vast amount of uncertainty with respect to salmon between the stressors and controlling factors in the conceptual model. Why monitor something if you don't know the effect on salmonid performance? 
Ebberts commented that the Estuary RME Plan was too big and cumbersome. The EOS agreed.

Next Steps (as of June 21, 2006)

The EOS decided that next steps could not be determined at the time because of the ongoing negotiations in the BiOp remand process to develop a new BiOp by early 2007. In effect, the Estuary RME Plan was put on hold pending results in the BiOp arena.

The official version of the Estuary RME Plan available to the public is still the August 2004 Estuary RME Plan. The May 2006 version has not yet been revised based on the internal comments mentioned above. This should occur in FY07.

\subsubsection{Estuary Data Management}

This FY06 objective was put on hold pending outcome of the regional data management initiative called the Northwest Environmental Data-Network (NED). NED will support the data management needs of PNAMP. NED's mission will involve regional data integration. NED will work to discover what the data gaps are, how to share the data, and to determine the quality of the data. In FY06, the EOS kept abreast of this data management effort.

\subsubsection{Estuary RME Conference}

The EOS participated in an estuary RME conference in Astoria, Oregon, on April 19-20, 2006. The event was called the Conference on Research, Monitoring, and Restoration in the Lower Columbia River, Estuary, and Nearshore Ocean. The proceedings (Johnson and Sutherland 2006) provide copies of the presentations, abstracts, speaker biographies, and notes on the question/answer sessions.

\subsubsection{PNAMP Estuary Workgroup}

The PNAMP estuary workgroup, which formed in FY05, was a minor activity for Project 2002-07700 resources in FY06. Overall, a main focus of the federal RME effort in FY06 continued to be to coordinate and integrate with PNAMP. This was true for the EOS and the PNAMP estuary workgroup as well. Note there was no official affiliation between these two groups. EOS members participated in the PNAMP estuary workgroup as representatives of their respective agencies. As part of Project 2002-07700, however, PNNL represented the EOS at the PNAMP estuary workgroup.

The PNAMP estuary workgroup met in fall 2005, then there was a hiatus until summer 2006. The group worked on an inventory of ongoing monitoring programs and projects. This inventory effort was led from the central PNAMP coordination/policy body. The monitoring inventory effort is ongoing by the Pacific States Marine Fisheries Commission. 


\subsection{Work Element 119 - Manage and Administer Project}

\subsubsection{FY05 PISCES Format}

BPA rolled out PISCES in FY05 and continued in FY06. Accordingly, we continued to provide input on Project 2002-077-00 to PISCES.

\subsubsection{FY07 SOW/Budget}

We developed and submitted the FY07 scope of work and budget for Project 2002-077-00 to BPA via PISCES in August 2006. Project work in FY07 will involve EOS, estuary PNAMP, and revisions to the RME plan.

\subsubsection{Accrual Data}

BPA required accrual data in early and late summer 2006 for FY06. We provided these data for Project 2002-077-00.

\subsection{Work Element 132 - Annual Report}

\subsubsection{Annual Report}

The document herein fulfills the annual report objective.

\subsubsection{Biennial Estuary RME Report}

The EOS proposed the idea for a biennial report on RME work in the Columbia River Estuary in their Estuary RME Plan (Johnson et al. 2004). Accordingly, the BPA included development of an outline for such a report as an objective in Project 2002-077-00 during FY05 and FY06. However, the EOS did not work on this topic in FY06. The purpose of the biennial report would be to summarize, synthesize, and evaluate new findings in the context of the major management questions. The biennial report would be a key part of the adaptive management process for RME in the Columbia River estuary. A draft outline follows (same as in FY05 Annual Report).

Title: Research, Monitoring, and Evaluation in the Columbia River Estuary: Biennial Report, 2007

Front-of-the-Book

Title page

Disclaimer page

Executive Summary

Preface 
Table of Contents

List of Figures

List of Tables

Acronyms

Glossary

Chapter 1 - Introduction [[why, when, where]]

Purpose

Background

Study Area

Contents

Chapter 2 - Management Needs [[what the RME work is intended to address, i.e., the drivers for the research and monitoring]]

Introduction

Goals [[key management questions]]

Objectives [[link to Estuary RME Plan]]

Chapter 3 - Research and Monitoring [[describe what's being done to address management needs]]

Introduction

Programs and Funding Processes

Performance Indicators and Monitored Attributes [[link to Estuary RME Plan]]

Project Descriptions [[objectives, methods (briefly), and types of data]]

Summary

Chapter 4 - Synthesis of Major Findings [[tie the RME results together]]

Introduction

Major Findings

Synthesis

Chapter 5 - Assessment [[gap analysis, i.e., how well is the RME meeting management needs]] Introduction

Gap Analysis

Chapter 6 - Conclusions and Recommendations

Chapter 7 -- References 


\subsection{Work Element 141 - Status Reports}

Status reports on Project 220-077-00 were submitted quarterly by PNNL to BPA in FY06 - GE Johnson. They describe the activities and accomplishments for a given month and planned activities for the next month. In FY07, project status reports will continue to be produced quarterly.

\subsection{Work Element 174 - Produce Plan}

This work element pertains to the Estuary RME Plan that was released for internal review in May 2006 (Johnson et al. 2006). During FY05 and FY06, we received comments from numerous reviewers, including the ISRP. The reviewers generally supported the ecosystem-basis, structure, and content of the Estuary RME Plan. Some of their major concerns, however, included unclear programmatic goals, inconsistent and sometimes immeasurable objectives, weak development and application of the conceptual ecosystem model, ineffectual performance indicators, under-developed sampling designs, and no apparent standard monitoring protocols. Furthermore, the Plan's section containing the actions recommended to implement the Plan needed more specifics. For example, exactly how would the adaptive management process work and who would be in charge? Based on review comments, we worked to revise the Estuary RME Plan during 2006. The FY06 revisions were substantial. The FY06 revised Estuary RME Plan (Johnson et al. 2006) was delivered to BPA in May 2006.

\subsection{Summary of Accomplishments}

In summary, accomplishments during FY06 from Project 2002-077-00 were as follows:

- Continued facilitation and coordination of the EOS as it worked to respond to reviewer comments on the Estuary RME Plan, initiated implementation of the Plan, and provided input to the federal RME effort.

- Participated in the Conference on the Columbia River estuary RME in Astoria, Oregon, during April 19-20, 2006.

- Contributed to PNAMP's estuary workgroup by helping develop the inventory for monitoring programs and projects from Northern California to Puget Sound.

- Refreshed data on Project 2002-077-00 in BPA’s project tracking system, PISCES.

- Submitted quarterly status report describing project activities, accomplishment, and planned tasks.

- Delivered a revised Estuary RME Plan to BPA (May 2006). 


\subsection{Recommendations for FY07}

For FY07, we offer the following recommendations for activities for Project 2002-077-00, organized by work elements:

118 Coordination -- Continue facilitation of the estuary/ocean RME subgroup, including coordination with:

- RME Technical/Policy Oversight Group and Federal Caucus - attend meetings and provide status reports as required;

- PNAMP estuary workgroup - attend and participate in workgroup meetings and assist in the development of coordinated estuary planning and monitoring approaches within PNAMP;

- CSMEP - inform CSMEP about estuary RME activities and coordinate as necessary;

- $\quad$ RME Data Management Subgroup -- coordinate the estuary RME work with the developing data management effort for the basin-wide RME;

- $\quad$ NPCC and UPA -- Convene biennial estuary RME workshops to present new data, evaluate the conduct of the estuary RME program, exchange information, and provide input to the estuary/ocean RME subgroup.

119 Project Management -- Manage and administer the project according to BPA's "Work Element/Milestone” based project management and reporting system (PISCES).

132 Annual Report -- Produce an annual report of project activities, including a detailed outline for a biennial estuary RME summary report incorporating adaptive management recommendations at the program level for submittal to the Action Agencies, estuary restoration project leaders, and other related entities (e.g., subbasin planners, PNAMP).

141 Status Reports -- Produce quarterly status reports.

174 Plan -- Revise the estuary-RME plan (dated May 2006) as necessary as new information becomes available concerning RME in the Columbia River estuary. 


\subsection{Literature Cited}

Berquam, T.B., B.D. Ebberts, and J. Wilcox. 2003. Action Plan to Implement the FCRPS Biological Opinion in the Columbia River Estuary. Submitted to NOAA Fisheries, Portland, Oregon. September 30, 2003.

Bottom, D. L., K. K. Jones, and J. J. Herring. 1984. Fishes of the Columbia River Estuary. Internal report, 113, P. Available from Columbia River Data Development Program, Astoria OR. (Managed by Columbia River Estuary Taskforce, www.columbiaestuary.org.)

Bottom, D.L., C.A. Simenstad, A.M. Baptista, D.A. Jay, J. Burke, K.K. Jones, E. Casillas, and M. Schiewe. 2001. Salmon at River's End: The Role of the Estuary in the Decline and Recovery of Columbia River Salmon. DRAFT by NOAA Fisheries. Seattle, Washington.

Columbia River Estuary Data Development Program (CREDDP). 1984a. Index to CREDDP Data. Compiled by H.T. Mercier. S. Bell, ed. Columbia River Estuary Study Taskforce, Astoria, Oregon.

Columbia River Estuary Data Development Program (CREDDP). 1984b. Abstracts of Major CREDDP Publications. Compiled by D. Fox. Columbia River Estuary Study Taskforce, Astoria, Oregon.

Dawley, E.M., R.D. Ledgerwood, and A.L. Jensen. 1985a. Beach and Purse Seine Sampling of Juvenile Salmonids in the Columbia River Estuary and Ocean Plume, 1977-1983; Volume I; Procedures, Sampling Effort and Catch Data. U.S. Dep. Commerce, NOAA Tech. Memo. NMFS, F/NWC-74:1260.

Dawley, E.M., R.D. Ledgerwood, and A.L. Jensen. 1985b. Beach and Purse Seine Sampling of Juvenile Salmonids in the Columbia River Estuary and Ocean Plume, 1977-1983; Volume II; Data on Marked Fish Recoveries. U.S. Dep. Commerce, NOAA Tech. Memo. NMFS, F/NWC-75:1-397.

Dawley, E.M., R.D. Ledgerwood, T.H. Blahm, C.W. Sims, J.T. Durkin, R.A. Kirn, A.E. Rankis, G.E. Monan, and F.J. Ossiander. 1986. Migrational Characteristics, Biological Observations, and Relative Survival of Juvenile Salmonids Entering the Columbia River Estuary, 1966-1983. Report to Bonneville Power Admin., Portland, Oregon. Contract DACW57-85-F-0623, 256 p.

Durkin, J.T., T. Blahm; G. McCabe, T. Coley, R. McConnell, R. Emmett, and W. Muir. 1981. Columbia River Estuary Data Development Program Report: Salmonid and Non-Salmonid Fish. Study managed by Columbia River Estuary Study Taskforce for the Pacific Northwest River Basins Commission, Vancouver, Washington. 146 pages.

Dyer, K.R. and R.J. Orth, eds. 1994. Changes in Fluxes in Estuaries: Implications from Science to Management. Proceedings of ECSA22/ERF Symposium, 13-18September 1992, Institute of Marine Studies, University of Plymouth. Olsen \& Olsen, Fredensborg.

Fresh, K.L., E. Casillas, L.L. Johnson and D.L. Bottom. 2004. Role of the Estuary in the Recovery of Columbia River Basin Salmon and Steelhead: an Evaluation of Selected Factors on Population Viability. NOAA Technical Memorandum, Northwest Fisheries Science Center, National Marine Fisheries Service, NOAA, Seattle, WA, May 2004. 
Fuhrer, G.J., D.Q. Tanner, J.L. Morace, S.W. McKenzie and K.A. Skach. 1996. Water Quality of the Lower Columbia River Basin: Analysis of Current and Historical Water-Quality Data through 1994. U.S. Geological Survey Water-Resources Investigations Report 95-4294, prepared in cooperation with the Lower Columbia River Bi-State Water-Quality Program, Portland, Oregon. Available URL: www.lcrep.org

Independent Scientific Review Panel (ISRP). 2004. Comments on 1) Lower Columbia River Ecosystem and Data Management Project, and 2) Final draft Estuary RME Plan. Prepared for the Northwest Power and Conservation Council, Portland, Oregon, November 18, 2004. ISRP 2004-16.

Johnson, G. and B. Sutherland (eds.). 2006. Conference on Research, Monitoring, and Restoration in the Lower Columbia River, Estuary, and Nearshore Ocean. Proceedings from a conference in Astoria, Oregon on April 19-20, 2006. Available at http://cerc2006.pnl.gov/.

Johnson, G., H. Diefenderfer, B. Ebberts, C. Tortorici, T. Yerxa, S. McEwen, J. Leary, and J. Skalski. 2006. Federal Columbia River Estuary Research Monitoring and Evaluation Program. Bonneville Power Administration. Portland, Oregon. May 2006.

Johnson, G., H. Diefenderfer, T. Berquam, B. Ebberts, C. Tortorici, and J. Wilcox. 2004. Plan for Research Monitoring and Evaluation of Salmon in the Columbia River Estuary. Final draft prepared August 10, 2004, for the Bonneville Power Administration, Portland, Oregon, by the Pacific Northwest National Laboratory, Richland, Washington.

Johnson, G. and seven co-authors. 2003. An Ecosystem-Based Approach to Habitat Restoration Projects with Emphasis on Salmonids in the Columbia River Estuary. PNNL-14412, Final report submitted to the Bonneville Power Administration, Portland, Oregon, by the Pacific Northwest National Laboratory, Richland, Washington.

Jordan, C., J. Geiselman, M. Newsom, and J. Athearn (eds.). 2003. Research, Monitoring \& Evaluation Plan for the NOAA-Fisheries 2000 Federal Columbia River Power System Biological Opinion. Draft dated September 11, 2003. NOAA Fisheries, Bonneville Power Administration, U.S. Army Corps of Engineers, and Bureau of Reclamation.

Kirn, R.A., R.D. Ledgerwood, and A.L. Jensen. 1986. Diet of Subyearling Chinook Salmon (Oncorhynchus tshawytscha) in the Columbia River Estuary and Changes Effected by the 1980 Eruption of Mount St. Helens. Northwest Science 60: 191-196.

Ledgerwood, R.D., F.P. Thrower, and E.M. Dawley. 1991. Diel sampling of migratory juvenile salmonids in the Columbia River estuary. Fisheries Bulletin 89: 69-78.

Lower Columbia River Estuary Partnership and Lower Columbia Fish Recovery Board. 2004. Lower Columbia Salmon and Steelhead Recovery and Subbasin Plan. Volume I and II. Draft report prepared for the Northwest Power and Conservation Council, May 28, 2004. Available URL: http://www.nwcouncil.org/fw/subbasinplanning/lowerColumbia/plan/.

Lower Columbia River Estuary Program (now called Partnership). 1999. Lower Columbia River Estuary Plan, Comprehensive Conservation and Management Plan. Volume I, Portland, Oregon.

McCabe, G.T. Jr., R.L. Emmett, W.D. Muir, and T.H. Blahm. 1986. Utilization of the Columbia River 
Estuary by Subyearling Chinook Salmon. Northwest Science, Vol. 60, No. 2, pp.113-124.

McCabe, G.T. Jr., W.D. Muir, and J. T. Durkin. 1983. Interrelationships between juvenile salmonids and nonsalmonid fish in the Columbia River Estuary. U.S. Bur. Fish. Bull. 81: 815-826.

McConnell, R., T Blahm, G. Jr McCabe, T. Clocksin, T. Coley, J. Durkin, R. Emmett, and W. Muir. 1983. Columbia River Estuary Data Development Program Data Report: Salmonid and NonSalmonid Fish, four volumes. Columbia River Estuary Data Development Program. Managed by Columbia River Estuary Taskforce, Astoria, Oregon.

National Marine Fisheries Service (NMFS). 2000. Federal Columbia River Power System Biological Opinion: Re-initiation of Consultation on Operation of the Federal Columbia River Power System, Including the Juvenile Fish Transportation Program, and 19 Bureau of Reclamation Projects in the Columbia Basin. NMFS-NWR, Seattle, Washington. December 2000.

National Marine Fisheries Service (NMFS). 2004. Federal Columbia River Power System Biological Opinion: Reinitiation of Consultation on Operation of the Federal Columbia River Power System, Including the Juvenile Fish Transportation Program, and 19 Bureau of Reclamation Projects in the Columbia Basin. NMFS-NWR, Seattle, Washington. November 2004.

Pacific Northwest Aquatic Monitoring Partnership (PNAMP). 2004. Recommendations for Coordinating State, Federal, and Tribal Watershed and Salmon Monitoring Programs in the Pacific Northwest. Draft. Portland, Oregon. January 6, 2004.

PNAMP Estuary Workgroup 2005. Pacific Northwest Aquatic Monitoring Partnership Estuary Workgroup Strategy and Workplan. Draft submitted to the PNAMP Steering Committee on September 22, 2005. Available from J. Bos, Washington State Department of Ecology, Olympia, WA.

Pruter, A.T. and D.L. Alverson (eds.). 1972. The Columbia River Estuary and Adjacent Ocean Waters: Bioenvironmental Studies. University of Washington Press, Seattle, Washington.

Reimers, P.E., and R.E. Loeffel. 1967. The length of Residence of Juvenile Fall Chinook Salmon in Selected Columbia River Tributaries. Res. Briefs, Fish Comm. Oreg. 13(1): 5-19

Rich, Willis H. 1920. Early history and seaward migration of Chinook salmon in the Columbia and Sacramento rivers. U.S. Bur. Fish. Bull. 37: 2-73.

Small, L.F. (ed.). 1990. Columbia River: Estuarine System. Progress in Oceanography vol. 25, no. 1-4.

TetraTech. 1996. The Health of the River 1990-1996: integrated technical report. Report TC 0253-01, prepared by Tetra Tech for the Lower Columbia River Bi-State Program, May 20, 1996. Available URL: www.lcrep.org.

U.S. Army Corps of Engineers (USACOE). 2001. Biological Assessment Columbia River Channel Improvements Project. Submitted to NMFS and USFWS. December 28, 2001. Portland, Oregon. 
